\title{
Science advice: a year of dangerous living
}

From mad cows to 'Gulf War syndrome', 1996 was a year in which politicians faced increasing public demands for action on issues where scientific evidence pointed to a potential danger to human health but remained inconclusive on its precise nature.

Providing advice to government on technology-related risks has long been an important task for the scientific community. Yet inevitable difficulties in providing clear-cut leadership on issues where the interpretation of research results remains uncertain have put strain on the conventional mechanisms for providing scientific advice. So, too, has growing awareness of the role of subjective factors in risk perception.

A series of crises has stimulated governments to develop more sophisticated mechanisms for integrating both scientific advice and public perceptions into their risk-management policies. They have also generated active debate on the relationship between governments and their science advisers, on the impact of private sponsorship on science advice and on the role of the mass media in moulding public perceptions of risk.

On the following pages, Nature's correspondents around the world assess some of the key events and trends around which these debates have taken place in the past year. They range from the growing acceptance of genetic engineering in Germany and the fallout from Japan's food poisoning crisis, to the likely role of US scientists in framing new air pollution regulations.

The contexts - and issues - are very different from one another. But common threads, such as the role of governments in facilitating but not necessarily establishing consensus, and the value of openness and transparency (not forgetting peer review) in preparing science advice, are beginning to emerge; 1997 will show how rapidly they develop.

\section{How BSE crisis forced Europe out of its complacency}

Paris. Science stirred up a political storm last March when Stephen Dorrell, the British health minister, announced that the probable explanation for ten cases of a new variant of Creutzfeldt-Jakob disease (CJD) was that those affected had eaten beef contaminated with the agent causing bovine spongiform encephalopathy (BSE).

Dorrell's announcement to the House of Commons - based on the conclusions of the government's Spongiform Encephalopathy Advisory Committee (SEAC) brought to an abrupt and ignominious end a decade of reassuring messages from the government. These had relied on the premise that there was no scientific evidence that BSE could pass to humans and that, even if it could, adequate measures were in place to prevent the most infective parts of cattle entering the human food chain.

The UK government's U-turn plunged Europe into one of its biggest economic and political crises since the Second World War. The European Union (EU) imposed a ban on all UK exports of beef (see Nature 381, 354; 353; 1996), and consumers panicked at the sudden prospect of a CJD epidemic. Beef consumption across the EU in 1996 was 11 per cent down on 1995. By the end of this year, the BSE crisis will have cost the EU ECU3.5 billion (US $\$ 2.8$ billion) in subsidies to the beef industry.

The impact of the crisis on the public's esteem for scientific advice has been no less dramatic. The main message that the public appears to have retained is that, despite warning signals, structural weaknesses in the operation of the institutional framework meant that a dangerous complacency permeated the government, the scientific and medical communities and the media.

Investigations by both the press and the European Parliament have unearthed a

catalogue of errors by UK and EU authorities - in particular the failure adequately to enforce either abattoir controls or a 1988 ban on the feeding of ruminant protein to ruminants (see Nature 381, 544; 1996).

All this has led to a cacophony of demands for change in the way in which Britain and the EU organize the gathering of scientific advice (see Nature 384, 201 \& 8; 1996). Several common threads seem to be emerging. One is the desire to introduce a

\section{IMAGE UNAVAILABLE FOR COPYRIGHT REASONS}

to take over food regulation from the agriculture ministry. A similar separation of powers within the European Commission is likely to feature among the recommendations of a BSE inquiry set up by the European Parliament, which is scheduled to release its final report next month.

One proposal is expected to be to remove animal health and food safety from the agriculture and industry directorates, combine them with health - currently part of the

in directorate for employment and

$\sum_{\alpha}^{\infty}$ social affairs - and transfer these

a responsibilities to the directorate for consumer policy (see Nature 384, 8; 1996).

Pressure is also mounting in Britain and elsewhere for reform

$\&$ of the system of government scientific advisory committees. The UK Consumers' Association and Charter 88 (a body campaigning for constitutional reform) have demanded greater accountability by such committees (see Nature 384, 201; 1996).

One unpublished account of the operation of the commission's scientific veterinary committee will give critics further cause for concern. A 1990 memorandum

clearer institutional separation between public health and consumer protection on the one hand, and agricultural and industrial interests on the other.

Decision-making on BSE in the United Kingdom has been concentrated within the Ministry of Agriculture, Fisheries and Food, and at the European level within the European Commission's directorate for agriculture. Critics argue that this arrangement has allowed agricultural and economic interests to prevail over those of public health (see Nature 380, 273; 1996).

In the United Kingdom, both the opposition Labour party and consumer associations have called for an independent body written by one commission official, Gérard Castille, records how Fernando Mansito, deputy director general of the agriculture directorate, reprimanded the committee at a meeting on BSE in June 1990 for "only discussing free circulation [of products] and economic aspects", although its remit was to assess the risks to consumers. "On two occasions, he was obliged to remind the committee of its mandate," says the memorandum.

Franz Fischler, the European agriculture commissioner, has himself publicly stated that a reform of the commission's scientific advisory system is needed to re-establish its credibility and impartiality in the eyes of the public. 